\title{
ASSESSMENT OF SOME GENETIC AND ENVIRONMENTAL RISK FACTORS IN PATIENTS WITH CONGENITAL HEART DISEASES ASSOCIATED WITH PULMONARY HYPERTENSION
}

\author{
Ragab, M. H. ${ }^{(1)}$; El Ruby, Mona, O. ${ }^{(2)}$; Mohamed, Amal ${ }^{(2)}$ \\ and Abd Allah, Sally, G. \\ 1) Institute of Environmental Studies and Research, Ain Shams University \\ 2) National Research Centre
}

\begin{abstract}
Congenital heart disease (CHDs) -whether it is associated with pulmonary hypertension (PH) or not- is the most common malformation in children. It is an important cause of infant mortality, long term morbidity and disability.

Aim of the study is to assess the role of some genetic and environmental risk factors in patients with CHDs associated with $\mathrm{PH}$.

Subjects and methods: A case-control study was conducted and included 3 groups of cases; 37 patients with CHDs associated with $\mathrm{PH}, 37$ patients with CHDs and 37 children without any congenital malformations were taken as a control group. The following clinical information was collected through predesigned questionnaires: maternal age at conception; parental consanguinity; maternal gestational diabetes (DM) and hypertension, adverse reproductive history (abortions and still births); and maternal environmental tobacco smoking (ETS) and deficient folic acid intake during pregnancy. Cytogenetic study for patients in the first and second groups of cases was carried out.

Results: Chromosomal abnormalities were detected in $13.5 \%$ of patients with CHDs associated with $\mathrm{PH}$ and $10.8 \%$ of patients with CHDs. Maternal age, adverse reproductive history, maternal gestational DM and hypertension were not found to be significantly associated with congenital heart diseases in this study, while parental consanguinity, low maternal education level,
\end{abstract}


maternal ETS and deficient folic acid intake during pregnancy were significantly associated with CHDs.

Conclusion: It is crucial to make proper decisions and implement policies for lowering consanguineous marriages and provide proper pre-marital counseling and improving antenatal care to control the cases of CHDs.

Key words: CHDs, PH, risk factors, adverse reproductive history, DM, ETS.

\section{INTRODUCTION}

CHDs are one of the most prevalent and serious birth defects, and are the leading causes of birth defects-associated morbidity and mortality (Reller et al., 2008; Gilboa et al., 2010). Many studies in developed countries have estimated that approximately 40 to 100 per 10000 live births suffer from CHD (Reller et al., 2008; Zhang et al., 2011).

The etiology of most CHDs is not fully elucidated; only around $15 \%$ of CHDs can be attributed to a known cause (Botto and Correa, 2003; Mone et al., 2004). Approximately 5-10\% of CHDs are associated with chromosomal abnormality, $3-5 \%$ can be linked to defects in single genes, and about $2 \%$ are attributed to known environmental factors (Botto and Correa, 2003). It is difficult to establish the role of a single factor, because in many cases, the cause of a defect is believed to be multifactorial (Lin and Ardinger, 2005), including environmental teratogens with genetic and chromosomal conditions (Botto and Correa, 2003; Pei et al., 2017). Most of the causes of these defects occur within the fetal-placental-maternal "environment" and any of the environmental factors may affect the woman before pregnancy or during fetal development (Lin and Ardinger, 2005).

Pulmonary hypertension $(\mathrm{PH})$ is a severe vascular disease of the lungs leading to increased pulmonary artery pressure and eventually to death from 
right ventricular failure. The prevalence is estimated between 15 and 26 cases per 1 million people in Europe (Archer et al., 2010; Simonneau et al., 2013). $\mathrm{PH}$ is associated with CHDs in approximately $18 \%$ of patients with $\mathrm{PH}$. Patients with aorto-pulmonary window and AVSD (atrioventricular septal defects) have the highest risk of developing PH, while other CHDs associated with PH are aterial septal defects (ASD), ventiricular septal defects (VSD), truncus arteriosus (TA), persistent ductus arteriosus (PDA), double inlet left ventricle (DILV), double outlet right ventricle (DORV) and univentricular heart (Barst et al., 2014).

It is important to better understand the etiological factors (genetic and environmental) for these malformations, especially the modifiable ones, being a crucial step leading to proper strategies for prevention. This research work aimed at analysis of some genetic and environmental risk factors in a selected group of patients with CHDs associated with pulmonary hypertension.

\section{SUBJECTS AND METHODS}

\section{Setting:-}

The study has been carried out at the Clinical Genetics Clinic at Medical Centre of Excellency and the Cytogenetic department at National Research Centre (NRC), Egypt.

\section{Study design and population:-}

A case control study has been conducted between December 2014 and April 2017 and included three groups of cases that were nearly matching; the first group was a selected group (37) of patients with CHDs associated with $\mathrm{PH}$, the second was a group of (37) patients with CHDs. A control group of 
children (37) without any congenital malformations have been randomly chosen from Helwan general hospital outpatient clinic.

\section{Inclusion criteria:-}

Any patient with CHDs associated with $\mathrm{PH}$ (syndromic or non syndromic), aged between 1 day to 18 years and of both sexes has been included in the first group of cases.

\section{Ethical considerations:-}

Approval for the study has been obtained from the NRC (National Research Centre) ethical committee. Each patient's guardian has received full information about the aim and procedures of the study and those who freely consent to participate have been asked to sign the relevant form to indicate their consent before enrollment in the study.

\section{Data collection:-}

An evaluation form was completed by clinical geneticists for each patient participating in the study. This was carried out through direct interviews with patients and their parents for complete clinical genetic evaluation.

Using a pre-designed unified and structured questionnaire (Gładki et al., 2015); maternal socio-demographic information, relevant medical history and possible risk factors exposure have been recorded. The latter had been included: maternal age at conception, parental consanguinity, adverse reproductive history (abortions and stillbirths), maternal ETS, maternal disease (diabetes and hypertension) and deficient folic intake during pregnancy. 


\section{Cytogenetic studies:-}

Conventional cytogenetic studies were performed on peripheral blood lymphocyte culture using the standard protocol with modifications (Verma and Babu, 1995). A total of 25 well banded metaphase plates were analyzed and karyotyped according to the International System for Human Cytogenetic Nomenclature (ISCN 2016).

\section{Data analysis:-}

Data were analyzed using the statistical package for social sciences (SPSS) for Windows version 23. Analysis of variance employing the twotailed student and Chi square tests were used for evaluation of data, statistical significance was set at 0.05 .

\section{RESULTS}

This research work studied three groups of cases; the first group was patients with CHDs associated with $\mathrm{PH}$ ( $\mathrm{n}=37 ; 22$ females and 15 males), the second group was those patients with CHDs $(\mathrm{n}=37 ; 14$ females and 23 males) and the third one was a group of children $(\mathrm{n}=37 ; 21$ females and 16 males) who did not have any congenital malformations.

Chromosomal analysis was performed for the patients of the first and second groups of cases and the results were as follow and summarized in table1.

The first group of cases (CHDs-PH): Chromosomal abnormalities were detected in five patients $(n=5 ; 13.5 \%)$ while thirty-two (32) cases showed normal karyotypes (46,XX - 46XY) and described as follows. One female patient shows trisomy 21 (Down syndrome); 47, XX, +21 and two male 
patients with trisomy 18 (Edwards syndrome) $(47, \mathrm{XY},+18)$. Another female patient showed abnormal karyotype; 46,XX, add18q23 represented to the clinic with CHD, pulmonary hypertension and dysmorphic features including large protruded tongue, depressed nasal root, hypertelorism, microtia and low set ears. Karyotyping of both parents showed normal results $(46, \mathrm{XX}-$ 46,XY). furthermore a female patient with structural chromosomal abnormality; 46,XX,del(4)(p16.3) represented to the clinic with CHD with $\mathrm{PH}$, dysmorphic features including frontal bossing, low set ears, sparse hair and high arched palate and her brain MRI showed agenesis of corpus callosum. Karyotyping of the parents was normal (46,XX-46,XY).

The second group of cases (CHDs); chromosomal abnormalities were observed in four cases $(10.8 \%)$ while thirty-one (33) cases showed normal karyotypes (46,XX - 46,XY) and the abnormalities were as follows. A female patient with trisomy 18 (Edwards syndrome) $(47, \mathrm{XX},+18)$ who represented with CHD, dysmorphic features and failure to thrive. Another female patient with 46,XX,del(5)(p15) represented to the clinic with CHD and dysmorphic features and karyotyping of the parents were normal. A male patient with 46,XY,r(18)and normal karyotypes of the parents represented with CHD and dysmorphic features.

This study has evaluated the frequency and types of chromosomal abnormalities identified in patients with congenital heart diseases associated with $\mathrm{PH}$ versus those with $\mathrm{CHDs}$ and found no significant difference among both groups ( $\mathrm{p}$-value $=0.6$ ) as chromosomal abnormalities were observed in 
$13.5 \%$ of patients with CHD-PH versus $10.8 \%$ in cases with CHDs and the overall frequency of chromosomal abnormalities was $12.1 \%$.

Table (1): Summary of chromosomal abnormalities and the associated clinical features reported in this study.

\begin{tabular}{|c|c|c|c|c|c|}
\hline \multirow{2}{*}{$\begin{array}{l}\text { Pt. } \\
\text { no. }\end{array}$} & \multicolumn{2}{|c|}{$\begin{array}{c}\text { CHDs with Pulmonary } \\
\text { hypertension }\end{array}$} & \multirow{2}{*}{$\begin{array}{l}\text { Pt. } \\
\text { no. }\end{array}$} & \multicolumn{2}{|c|}{ CHDs } \\
\hline & $\begin{array}{l}\text { Clinical } \\
\text { features }\end{array}$ & Karyotype & & Karyotype & $\begin{array}{l}\text { Clinical } \\
\text { features }\end{array}$ \\
\hline 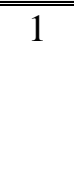 & $\begin{array}{l}\text { Mongoloid } \\
\text { facies }\end{array}$ & 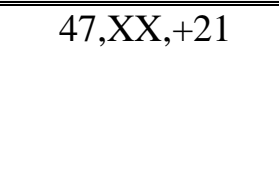 & $\begin{array}{l}1^{\prime} \\
\& \\
2^{\prime}\end{array}$ & 47,XX,+18 & $\begin{array}{c}\text { dysmorphic } \\
\text { features } \\
\text { failure } \\
\text { to thrive }\end{array}$ \\
\hline $\begin{array}{c}2 \& \\
3\end{array}$ & $\begin{array}{l}\text { Dysmorphic } \\
\text { features }\end{array}$ & $47, X Y,+18$ & $3^{\prime}$ & $\begin{array}{c}46, X X, \operatorname{del}(5) \\
(p 15)\end{array}$ & $\begin{array}{l}\text { Dysmorphic } \\
\text { features }\end{array}$ \\
\hline 4 & $\begin{array}{c}\text { dysmorphic } \\
\text { features } \\
\text { corpus } \\
\text { callosum } \\
\text { agenesis }\end{array}$ & $46, \mathrm{XX}$, add $18 \mathrm{q} 23$ & $4^{\prime}$ & $46, X Y,(r)(18)$ & $\begin{array}{c}\text { Dysmorphic } \\
\text { features } \\
\text { Delayed } \\
\text { milestones }\end{array}$ \\
\hline 5 & $\begin{array}{l}\text { dysmorphic } \\
\text { features }\end{array}$ & $\begin{array}{l}\text { 46,XX,del(4) } \\
\text { (p16.3) }\end{array}$ & & & \\
\hline
\end{tabular}

This work had evaluated some maternal and peri-natal risk factors in patients of the first two groups after excluding those with chromosomal abnormalities (cases that have definite cause) using the third group of participants (children without any congenital malformations) as a control group and no association of CHDs (both groups 1 and 2) with maternal age, adverse reproductive history, maternal diabetes mellitus and hypertension but parental consanguinity, low maternal education level, ETS and deficient intake of folic acid during pregnancy were significantly associated with cardiovascular malformations. These results have been summarized in table 2 and data are represented in the table as $\mathrm{n}$ and (\%) or mean \pm SD. Two-tailed 
student test (T) was used for comparison of numerical data and Chi square $\left(\chi^{2}\right)$ for the descriptive data.

Table (2): Maternal and some peri-natal risk factors for children with CHDs with normal karyotype

\begin{tabular}{|c|c|c|c|c|c|}
\hline Risk factor & $\begin{array}{c}\text { CHDs } \\
(\mathbf{n = 3 3 )}\end{array}$ & $\begin{array}{c}\text { CHD-PH } \\
(\mathbf{n = 3 2})\end{array}$ & $\begin{array}{c}\text { Total cases } \\
\text { of CHDs } \\
(\mathbf{n = 6 5})\end{array}$ & $\begin{array}{c}\text { Normal } \\
\mathbf{c o n t r o l} \\
(\mathbf{n = 3 7})\end{array}$ & P- value \\
\hline \hline Consanguinity & $18(58.06 \%)$ & $\begin{array}{c}19 \\
(59.3 \%)\end{array}$ & $\begin{array}{c}37 \\
(58.7 \%)\end{array}$ & $\begin{array}{c}12 \\
(32.4 \%)\end{array}$ & $\begin{array}{c}0.05 \\
\chi 2=3.963\end{array}$ \\
\hline Maternal age & $27.9 \pm 6.1$ & $26.3 \pm 5.2$ & $26.8 \pm 5.2$ & $25.9 \pm 5.5$ & $\begin{array}{c}0.6 \\
\mathrm{~T}=0.470\end{array}$ \\
\hline $\begin{array}{c}\text { Low maternal } \\
\text { education level }\end{array}$ & $\begin{array}{c}26 \\
83.8 \%\end{array}$ & $\begin{array}{c}25 \\
2\end{array}$ & $\begin{array}{c}51 \% \\
80.9 \%\end{array}$ & $\begin{array}{c}9 \\
24.3 \%\end{array}$ & $\begin{array}{c}0.000 \\
\chi 2=27.331\end{array}$ \\
\hline Still birth & $6.4 \%$ & $3.1 \%$ & $\begin{array}{c}3 \\
4.7 \%\end{array}$ & $\begin{array}{c}0.6 \\
\chi 2=0.245\end{array}$ \\
\hline Abortion & $\begin{array}{c}1 \\
22.7 \%\end{array}$ & $37.5 \%$ & $30.1 \%$ & $\begin{array}{c}9 \\
24.3 \%\end{array}$ & $\begin{array}{c}0.9 \\
\chi 2=0.004\end{array}$ \\
\hline DM & $1(3.5 \%)$ & $1(5.2 \%)$ & $2(4.2 \%)$ & $4(13.3 \%)$ & $\begin{array}{c}0.2 \\
\chi 2=1.845\end{array}$ \\
\hline Hypertension & $1(3.2 \%)$ & - & $1(1.5 \%)$ & $3(10.8 \%)$ & $\begin{array}{c}0.7 \\
\chi 2=0.186\end{array}$ \\
\hline ETS & $15(48.3 \%)$ & $26(81.2 \%)$ & $41(65.07 \%)$ & $9(24.3 \%)$ & $\begin{array}{c}0.000 \\
\chi 2=20.858\end{array}$ \\
\hline $\begin{array}{c}\text { Deficient intake } \\
\text { of folic acid }\end{array}$ & $5(16.1 \%)$ & $13(40.6 \%)$ & $18(28.5 \%)$ & $3(8.1 \%)$ & $\begin{array}{c}0.000 \\
\chi 2=27.715\end{array}$ \\
\hline
\end{tabular}

\section{DISSCUSION}

CHDs with $\mathrm{PH}$ are one of the most prevalent causes of morbidity and a major source of pediatric mortality around the world (Bernier et al., 2010). In recent years researchers declared various factors for developing this disease; generally, they divide these factors into two categories of environmental and genetic ones. Considering the fact that these factors could be different in 
various regions, it is crucial to conduct studies on our population to identify the contributing factors for developing the disease.

This research work included three groups of cases; the first group was patients with CHDs with $\mathrm{PH}(\mathrm{n}=37 ; 22$ females and 15 males), the second group was those patients with CHDs ( $\mathrm{n}=37 ; 14$ females and 23 males) and the third one ( $\mathrm{n}=37 ; 21$ females and 16 males) was a group of children who did not have any congenital malformations.

Reviewing the literature and identified many studies which evaluated the frequency and types of chromosomal abnormalities reported in patients with congenital heart diseases (whether associated with PH or not) (Meberg et al., 2000; Bosi et al., 2003; Calzolari et al., 2003; Harris et al., 2003; Amorim et al., 2008; Dadvand et al., 2009; Hartman et al., 2011; Trevisan et al., 2013). The frequency of chromosomal abnormalities identified in this study was (13.5\%) in patients with CHDs associated with $\mathrm{PH}, 10.8 \%$ in patients with CHDs and the overall frequency reported was $12.1 \%$ and these results were similar to that found in the studies by Harris et al., 2003, Amorim et al., 2008 and Trevisan et al., 2013 who found rates of 12.9-23.1\%. But differences observed in relation to the study by Meberg et al., 2000, Bosi et al., 2003, Calzolari et al., 2003, Dadvand et al., 2009 and Hartman et al., 2011 who found rates of $3-12.1 \%$. These were characterized by having distinct samples, both regarding the number and the clinical criteria of their patients.

The frequency of structural abnormalities detected in our study was $5.4 \%$ in groups 1 and group and this is consistent with most other studies (4.2 to $16.7 \%$ ), differing only in relation to Ferencz et al., 1997, who found a little bit lower frequency $(4.4 \%)$, however this study was the oldest. 
Regarding the numerical aberrations; full trisomy of chromosome 18 was the most frequent chromosomal abnormality detected in this study as it was reported in group 1 ( 2 patients) and recurrent among patients of group 2 (2 patients). Trisomy 18 was first reported by Edwards et al in 1960 and known also as Edwards syndrome which is characterized by broad clinical features with more than 130 different clinical presentations have been already described in literature (Cereda and Carey, 2012). CHDs have been described in around $80-100 \%$ of patients with Edwards's syndrome and the most frequently reported defect is VSD (Cereda and Carey, 2012) and this is consistent with this study as VSD was present in two patients with trisomy 18. Trisomy 21 or Down syndrome is the most frequent numerical chromosomal abnormality described in literature and CHDs reported in 40-50 $\%$ of the cases and it was detected in one patient (CHD with $\mathrm{PH}$ ) in this study as we did not target the cases of Down syndrome.

Regarding the structural abnormalities reported in this study; deletion of 4 p16 (group 1), deletion of chromosome 5p15 (group 2) have been well documented as syndromes that presented with CHDs. Deletion $4 \mathrm{p} 16$ which is known as Wolf-Hirschhorn syndrome presents with cardiac defects in around $30-50 \%$ of cases and most frequent defects described is ASD and VSD (Battaglia et al., 1999) and this is consistent with findings of this study. Chromosome 5p15 deletion is known as Cri du chat syndrome in which CHDs are present in $30 \%$ of cases (Hills et al., 2006).

Despite the many advanced technologies in cytogenetics that emerged in recent years with the development of molecular techniques, such as 
fluorescent in situ hybridization (FISH) and array comparative genomic hybridization $(\mathrm{aCGH})$, karyotyping remains a crucial and basic tool in genetic evaluation (Smeets, 2004). In this country, it is one of the few tests available for genetic evaluation of patients with congenital malformations. Despite its limitations in detecting small chromosomal rearrangements such as microdeletions or microduplications, the frequency of chromosomal abnormalities detected by karyotyping in patients with congenital heart disease is remarkable. Thus, clinicians, especially those working in pediatric cardiology field, should be aware of the implications that karyotype can bring, both for the diagnosis, treatment and prognosis of these patients, as well as for genetic counseling of their families.

Many previous studies have indicated that $70-85 \%$ of the cases of CHDs with $\mathrm{PH}$ are due to complex interaction between genetic and environmental factors (Botto and Correa, 2003), but the knowledge regarding the environmental risk factors and other risk factors for $\mathrm{CHD}$ with $\mathrm{PH}$ and the combined effect of genetic and environmental factors is still limited (Jenkins et al., 2007; Oyen et al., 2009).

This study analyzed some maternal conditions and peri-natal risk factors in the patients of CHDs (groups 1 and 2 in relation to the control group) after excluding those with ascertained genetic cause (chromosomal abnormality) to evaluate their association with the disease. Of these factors maternal age, abortions, still-births, maternal gestational diabetes mellitus and hypertension were not associated with a significant risk of CHDs (in both groups 1and 2), while consanguineous marriage, low maternal educational level, ETS and deficient intake of folic acid were significant risk factors. 
Regarding the maternal age; this study found no significant association with CHDs. There is controversy as mentioned in many studies like the BWIS (Baltimore Washington Infant Study) which reported that maternal age was not associated with non-genetic congenital heart defects (Ferencz et al., 1997), similarly Fung et al., 2013, Ma et al., 2014, Shi et al., 2015 and Liu et al., 2018 but analysis of non-chromosomal birth defects of the Metropolitan Atlanta Congenital Defects Program from 1968 to 2000 found associations of advanced maternal age (35 to 40 years) with an increased risk of all heart defects (Matalon et al., 2003), similarly other studies by Reefhuis and Honein, 2004.

Similarly another controversial issue; the history of abortions and stillbirths in previous pregnancies which have not been found to be associated with CHDs in this study and that was also reported by Liu et al., 2018 but Shi et al., 2015 has found significant relationship between history of abortions and stillbirths and the development of CHDs.

This study observed that maternal DM and hypertension were not significantly associated with CHDs. In regard to maternal gestational DM; there have been reports found association with maternal pregestational and less consistently with gestational diabetes (Ferencz et al., 1997; Sharpe et al., 2005). The associations with gestational diabetes are hypothesized to be due to inclusion of a group of women with previously undetected type 2 diabetics among those classified as having gestational diabetes (Sheffield et al., 2002), similarly Fung et al., 2013 and Ma et al., 2014 found no significant 
relationship between gestational diabetes and CHDs and they also reported no significant association of CHDs with maternal hypertension.

In respect to deficient folic acid intake; this study detected significant association with CHDs; supportive evidence from meta- analysis studies of the Hungarian randomized trial on birth defects which evaluated the possibility that peri-conceptional intake of folic acid may reduce the risk of CHDs (including those with $\mathrm{PH}$ ) in offspring, similar to the known risk reduction for neural tube defects seen with folic acid (Jenkins et al., 2007). Findings from similar studies have been generally supportive but not conclusive (Werler et al., 1999; Shi et al., 2015). Additional studies are required to determine whether the association of CHDs with folic acid can be corporated in large population based studies, potential confounders such as maternal age and diabetes can be taken into consideration.

This study observed that the exposure to ETS during pregnancy among CHDs mothers was higher than the normal control group. This finding is consistent with a study carried out in Italy showing increased CHDs in children whose fathers were smokers (Cresci et al., 2011). Another casecontrol study conducted in Lithuania (Kuciene and Dulskiene, 2010) showed paternal smoking was associated with increased exposure to ETS, and a more recent study by Liu et al., 2018 have found supportive evidence that maternal ETS was significantly associated with CHDs.

ETS is an important public health problem in Egypt and it is estimated that Egypt is one of 15 countries worldwide with a heavy burden of tobacco related illness and according to WHOs 2013 standardized estimates of smoking prevalence; $40.5 \%$ of men, $0.3 \%$ of women and $20.3 \%$ of Egypt's 
overall population are daily tobacco smokers (Loffredo et al., 2015). Of current male smokers around 50\% are aged between 25 - 44 years suggesting a large proportion of their wives of similar ages would be exposed to ETS if they get pregnant.

This study observed that low socio-demographic indicators such as low maternal education level was significantly associated with CHDs. This finding was consistent with the hypothesis that low socioeconomic status is associated with higher odds of CHDs (Rogers et al., 1998). As Yang et al., 2008 have stated that education reflects a person's ability to access and interpret health related information and the conditions that affect health, living condition, medical care and lifestyle, similar findings were observed in a study carried out by Liu et al., 2018.

These findings provide insight in identifying modifiable risk factors in vulnerable populations, and the need to plan evidence-based interventions for pregnant women and their partners to reduce the burden of CHDs, particularly for those with low socioeconomic status.

Furthermore results of this study indicated that the parental consanguinity was an important risk factor for CHDs as higher proportion of consanguineous marriages among patients with CHDs (associated with $\mathrm{PH}$ or not) in comparison to the control group. This finding is consistent with the majority of studies which supports the relationship between consanguineous parentage and CHDs in the offspring as in Becker et al., 2001 who found significant association between first cousin marriage and congenital heart defects, another study have been carried out by Nabulsi et al., 2003 who 
analyzed a number of demographic parameters in their case group for example gender, age, education level and they reported that consanguinity could lead to segregation of autosomal recessive genes and so concluded the potential role of a multifactorial etiology in CHDs, similarly, Chehab et al., 2007 and Dev et al., 2016. However, a study by Fung et al., 2013 found no association between consanguineous marriage and CHDs in the off springs however this may be attributed to ethnic diversity in Ontario. This finding should raise our attention to the significance of premarital counseling and avoiding consanguineous marriages via public health education so declining the rates of CHDs in our population.

\section{CONCLUSION}

In summary, this study is focusing on the increasing burden of genetic and environmental risk factors for CHDs (associated with PH or not) in the current era as evidence emerged of multi-factorial etiology of CHDs. It highlights a growing need for better surveillance for CHDs both antenatally and postnatally, routine ascertainment and counseling regarding environmental exposures during pregnancy, routine family history in all affected pregnancies, and better genetic screening technology. Public health advocacy measures to reduce environmental risk especially for modifiable factors like smoking, consanguineous marriage and low educational level are important. Consideration should be given to routine antenatal screening for CHDs in women with multiple risk factors including advanced maternal age, preexisting maternal conditions and maternal exposure to known teratogens. Ultimately, this knowledge can be used for early prevention, early risk 
stratification, and the development of targeted diagnostics and therapies to reduce the health and economic burden of CHDs associated with $\mathrm{PH}$.

\section{RECOMMENDATION}

This study has recommended performing a population based study among the Egyptian infants with congenital heart defects to assess the role of genetic and environmental factors in development of the disease.

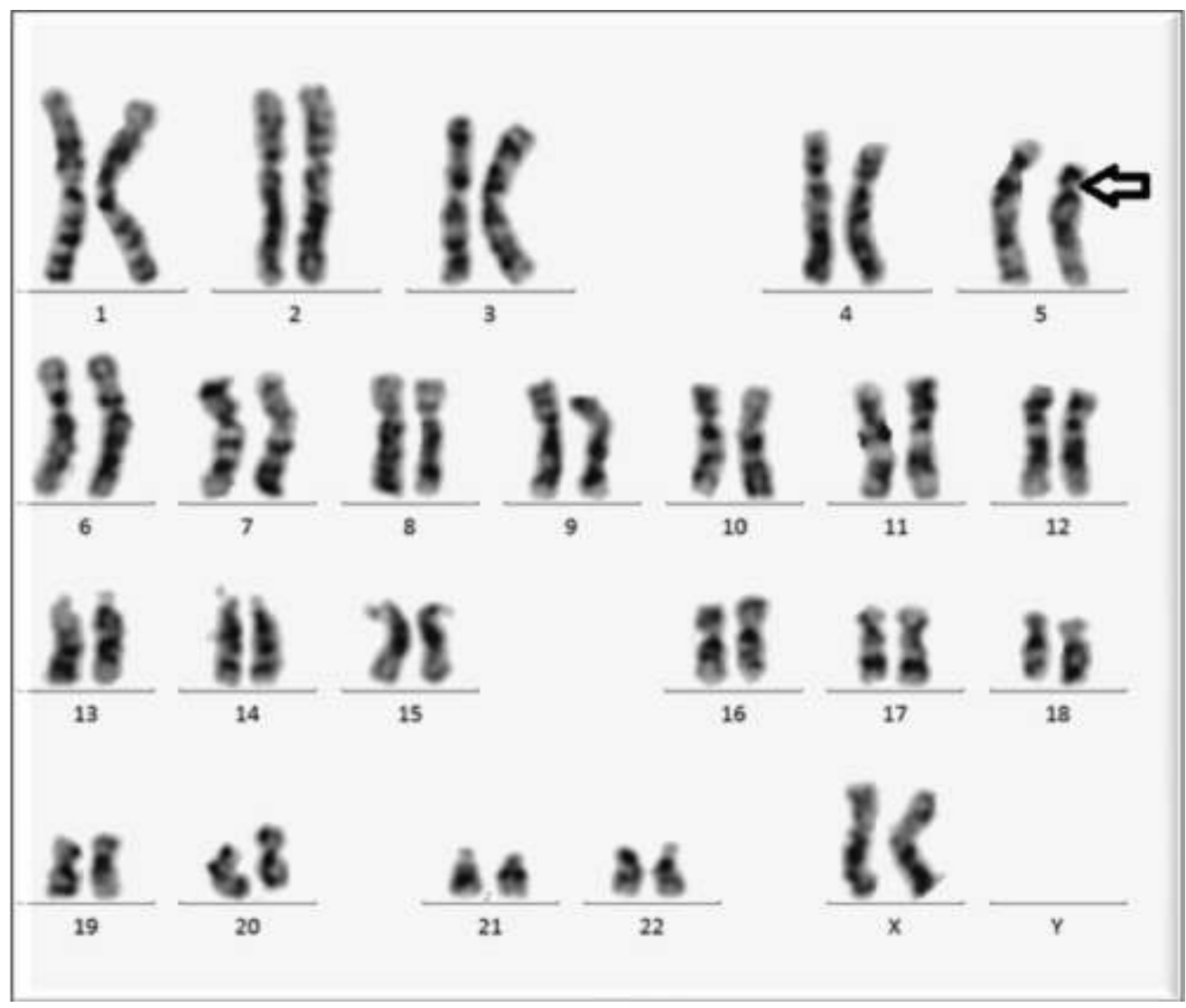

Fig. (1): GTG banded karyotype showing a case of 46,XX,del(5)(p15) 


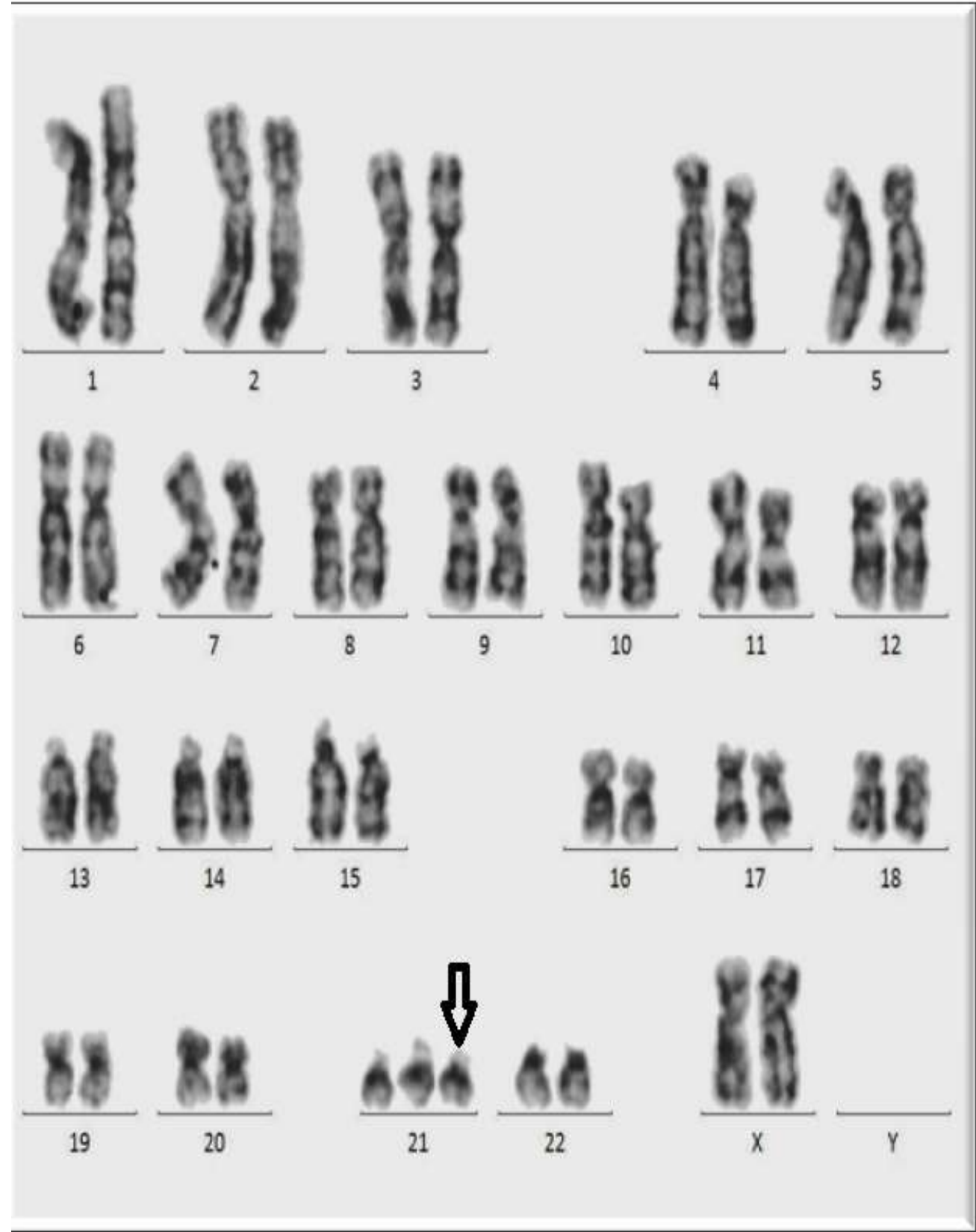

Fig. (2): GTG banded karyotype showing a case of $47, X X,+21$ 
J. Environ. Sci.

Institute of Environmental Studies and Research - Ain Shams University

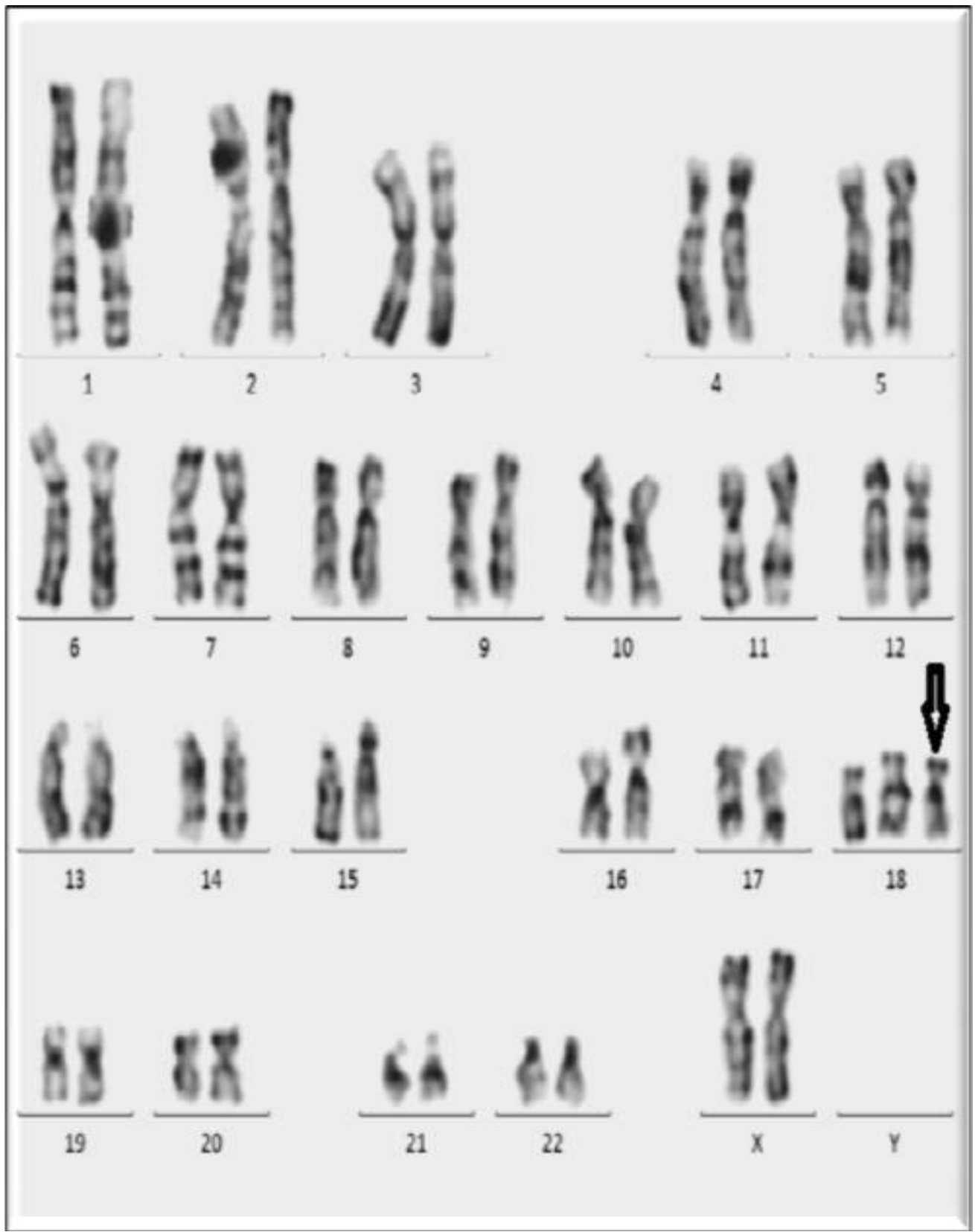

Fig. (3): GTG banded karyotype showing a case of $46, X X,+18$

66

Vol. 41, No.3, March 2018 


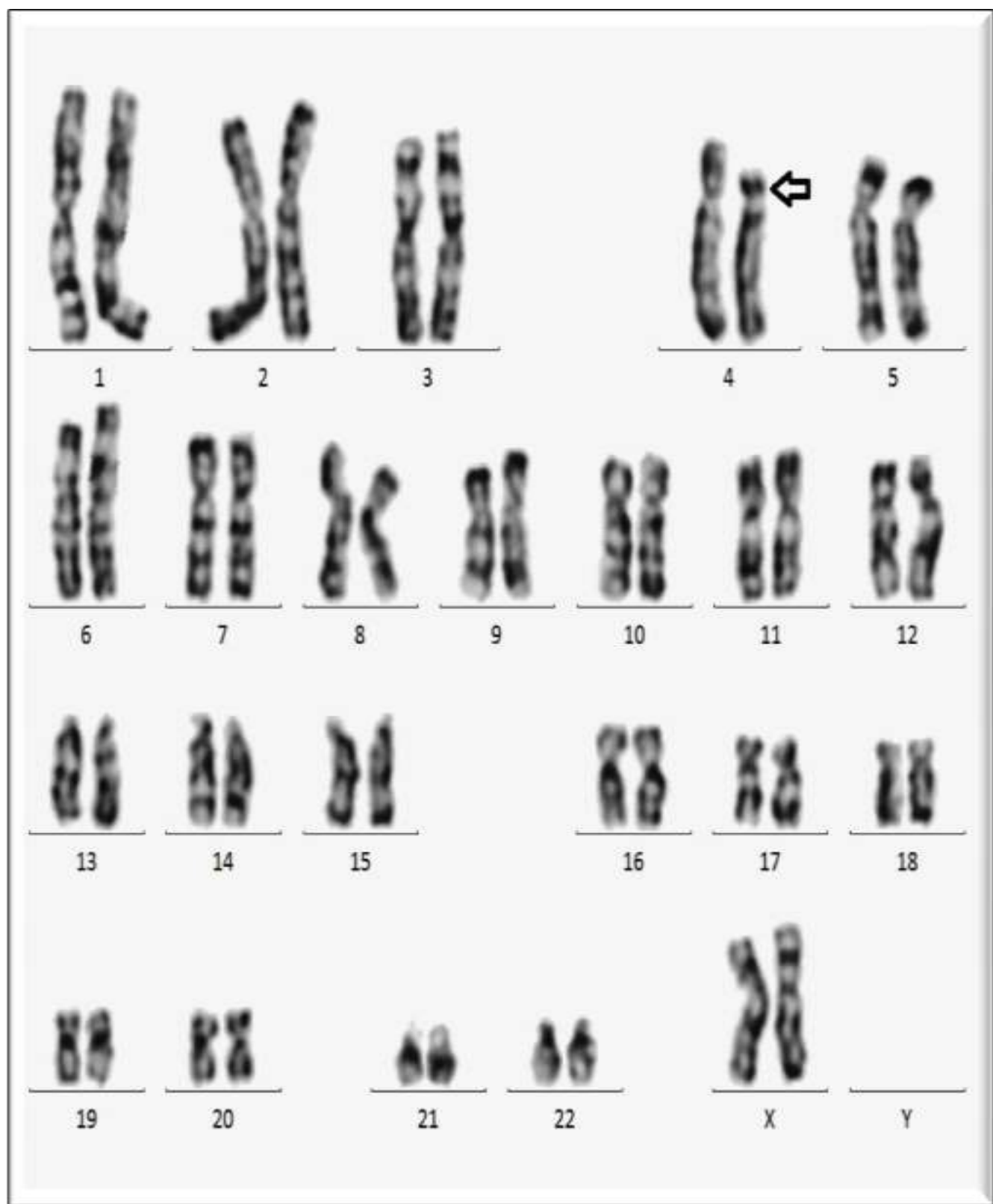

Fig. (4): GTG banded karyotype showing a case 46,XX,del(4)(p16) 


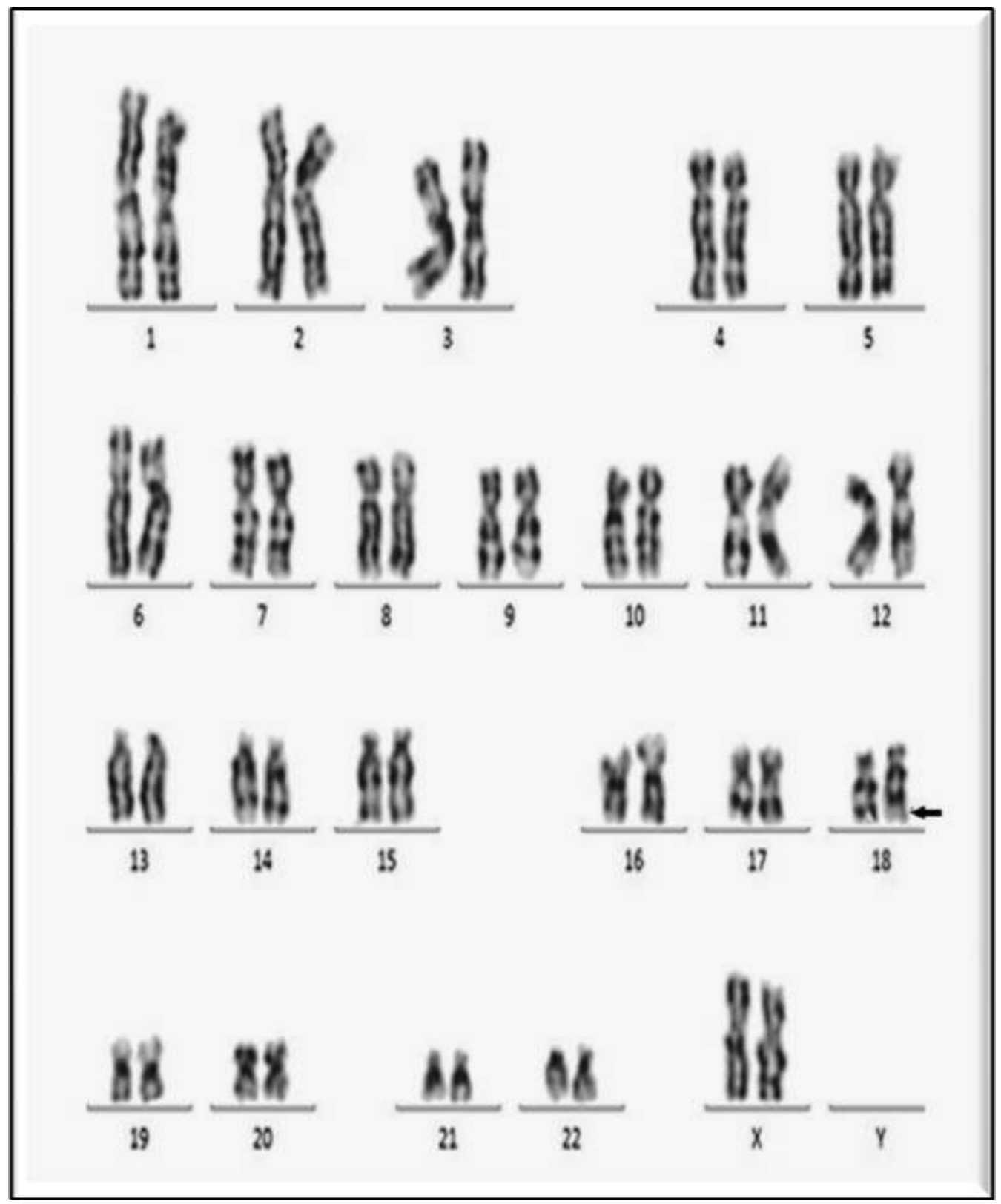

Fig. (5): GTG banded karyotype showing a case of 46,XX, add(18)(q23) 


\section{REFERENCES}

Amorim, L. F.; Pires, C.A.; Lana, A. M.; Campos, A. S.; Aguiar, R. A. \& Tibúrcio, J. D. et al. (2008): Presentation of congenital heart disease diagnosed at birth: analysis of 29,770 newborn infants: $\mathbf{J}$ Pediatr (Rio J).;84(1):83-90.

Archer, S. L.; Weir, E. K. \& Wilkins, M. R. (2010): Basic science of pulmonary arterial hypertension for clinicians: New concepts and experimental therapies. Circulation; 121:2045-2066.

Barst, R. J.; Ivy, D. D.; Foreman, A. J.; McGoon, M. D \& Rosenzweig, E. B (2014): Four and seven year outcomes of patients with congenital heart disease-associated pulmonary arterial hypertension (from the REVEAL registry): Am J Cardiol.; 113:147-155.

Becker, S. M.; Al-Halees, Z.; Molina, C. \& Paterson, R. M (2001): Consanguinity and congenital heart disease in Saudi Arabia: Am J Med Genet.; 99:8-13.

Bernier, P. L.; Stefanescu, A.; Samoukovic, G. \& Tchervenkov, C. I (2010). The challenge of congenital heart disease worldwide: Epidemiologic and demographic Facts. Pediatric Cardiac Surgery Annual 26-34, ISSN 1092-9126.

Bosi, G.; Garani, G.; Scorrano, M.; Calzolari, E. \& IMER Working Party (2003): Temporal variability in birth prevalence of congenital heart defects as recorded by a general birth defects registry: J Pediatr; 142(6):690-8.

Botto, L. D.; Lin, A. E.; Riehle-Colarusso, T.; Malik, S. \& Correa, A. (2007): Seeking causes: classifying and evaluating congenital heart defects in etiologic studies: Birth Defects Res: Part A-Clinical Mol. Teratol; 79 (10), 714-727.

Botto, L. D. \& Correa, A. (2003): Decreasing the burden of congenital heart anomalies: an epidemiologic evaluation of risk factors and survival: Prog Ped Cardiol.; 18:111-21. 
Calzolari, E.; Garani, G.; Cocchi, G.; Magnani, C.; Rivieri, F.; Neville, A. et $a l .$, \& IMER Working Group (2003): Congenital heart defects: 15 years of experience of the Emilia-Romagna Registry (Italy): Eur J Epidemiol.;18(8):773-80.

Cereda, A. \& Carey (2012): The trisomy 18 syndrome: Review; Orphanet Journal of Rare Diseases, 7:81.

Chéhab, G. (2007): Congenital heart disease, maternal age and parental consanguinity in children with Down's syndrome. J Med Liban.: 55(3); 133-7.

Cresci, M.; Foffa, I.; Ait-Ali, L.; Pulignani, S.; Gianicolo, E. A.; Botto, N.; Picano, E. \& Andreassi, M. G. (2011): Maternal and paternal environmental risk factors: metabolizing GSTM1 and GSTT1 polymorphisms and congenital heart disease: Am. J. Cardiol;108 (11), 1625-1631.

Dadvand, P.; Rankin, J.; Shirley, M. D.; Rushton, S. \& Pless-Mulloli, T. (2009): Descriptive epidemiology of congenital heart disease in Northern England: Paediatr Perinat Epidemiol.; 23(1):58-65.

Dev, D.; Sharma, R.; Sharma, M.; Agrawal, K. \& Garg, M. (2016): Evaluation of consanguinity as a risk factor for congenital heart diseases: Int J Contemp Pediatr.; 3(3):868-871.

Edward, J. H., Harnden, D. G.; Cameron, A. H.; Crosse, V. M. \& Wolf, O. H. (1960): A new trisomic syndrome; Lancet; (1): 787-789.

Ferencz, C.; Correa-Villasenor, A. \& Loffredo C. A. (1997): Genetic and environmental risk factors of major cardiovascular malformations: The Baltimore-Washington Infant Study: 19811989. Armonk, NY: Futura Publishing Co.

Ferencz, C.; Correa-Villasenor, A. \& Loffredo, C. A. eds. Genetic and Environmental Risk Factors of Major Cardiovascular Malformations: The Baltimore-Washington Infant Study: 19811989. Armonk, NY: Futura Publishing Co; 1997. 
Fung, A.; Manlhiot, C.; Naik, S.; Rosenberg, H.; Smythe, J.; Lougheed, J.; Mondal, T.; Chitayat, D.; McCrindle, B. W \& Mital, S. (2013): Impact of prenatal risk factors on congenital heart disease in the current era: J Am Heart Assoc.; (2): 364-390.

Gilboa, S. M.; Correa, A.; Botto, L. D.; Rasmussen, S. A.; Waller, D. K.; Hobbs, C. A.; Cleves, M. A. \& Riehle-Colarusso, T. J. (2010): National Birth Defects Prevention Study: Association between prepregnancy body mass index and congenital heart defects: Am J Obstet Gynecol.; 202:51.

Gładki1 M.; Składzień, T. \& Skalski, J. (2015): The impact of environmental factors on the occurrence of congenital heart disease in the form of hypoplastic left heart syndrome: Congenital heart disease in children and adults: Kardiochirurgia i Torakochirurgia Polska; 12 (3): 204-207.

Harris, J. A.; Francannet, C.; Pradat, P. \& Robert, E. (2003): The Epidemiology of cardiovascular defects, part 2: a study based on data from three large registries of congenital malformations: Pediatr Cardiol.; 24(3):222-35.

Hartman, R. J.; Rasmussen, S. A.; Botto, L. D.; Riehle-Colarusso, T.; Martin, C. L. \& Cragan, J. D. et al. (2011): The contribution of chromosomal abnormalities to congenital heart defects: a population-based study: Pediatr Cardiol; 32(8):1147-57.

Jenkins, K. J.; Correa, A.; Feinstein, J. A.; Botto, L.; Britt, A. E.; Daniels, S. R.; Elixson, M.; Warnes, C. A \& Webb. C. L. (2007): Noninherited risk factors and congenital cardiovascular defects: current knowledge: Circulation.;115:2995-3014.

Kuciene, R. \& Dulskiene, V. (2010): Parental cigarette smoking and the risk of congenital heart septal defects: Med. Kaunas. Lith; 46 (9), 635641.

Lin, A. E. A \& Ardinger, H. H. (2005): Genetic epidemiology of cardiovascular malformations: Progr Pediatr Cardiol; 20:113-26. 
Liu, X.; Nie, Z.; Chen, J.; Guo, X.; Ou, Y.; Chen, G.; Mai, J.; Gong, W.; Wu, Y.; Gao, X.; Qu, Y.; Erin, M.; Bell, E. M.; Lin, S. \& Zhuang J(2018): Does maternal environmental tobacco smoke interact with socialdemographics and environmental factors on congenital heart defects?: Env.pollution; 234, 214-222.

Loffredo, C. A.; Radwan, G. N.; Eltahlawy, E. M.; El-Setouhy, M.; Magder, L. \& Hussein, M. H. (2015): Estimates of the prevalence of Tobacco smoking in Egypt: Open Journal of Epidemiology; 5, 129-135.

Ma, D. H.; Xu, H. M.; Lin, N.; Yu, R. B.; Sun, X. R. \& Ding, K. Q. et al., (2014): Meta analysis of risk factors of congenital heart disease of Chinese Perinatal children. Acta Universitatis Medicinalis Nanjing; 34:1273-1278.

Matalon, K. M.; Acosta, P. B. \& Azen, C. (2003): Role of nutrition in pregnancy with phenylketonuria and birth defects: Pediatrics; 112(2):1534-1536.

Meberg, A.; Otterstad, J. E.; Frøland, G.; Lindberg, H. \& Sørland, S. J. Outcome of congenital heart defects - a population-based study. Acta Paediatr. 2000; 89(11):1344-51.

Mone, S. M.; Gillman, M. W.; Miller, T. L.; Herman, E. H.; \& Lipshultz, S. E. (2004): Effects of environmental exposures on the cardiovascular system: prenatal period through adolescence. Pediatrics 2004; 113:1058-69.

Nabulsi, M. M.; Tamim, H.; Sabbaqh, M.; Obeid, M. Y.; Yunis, K. A. \& Bitar, F. F. (2003): Parental consanguinity and congenital heart malformations in a developing country: Am J Med Genet A.; 116A (4), 342-7.

Oyen, N.; Poulsen, G.; Wohlfahrt, J.; Boyd, H. A.; Jensen, P. K. \& Melbye, M. (2009): Recurrence of discordant congenital heart defects in families: Circulation 3 (2), 122. 
Pei, L.; Kang, Y.; Zhao, Y. \& Yan, H. (2017): Prevalence and risk factors of congenital heart defects among live births: a population-based cross-sectional survey in Shaanxi province, Northwestern China: BMC Pediatrics; 17:18 -017-0784-1.

Reefhuis, J. \& Honein, M. A. (2004): Maternal age and non-chromosomal birth defects, Atlanta-1968-2000: teenager or thirty-something, who is at risk? Birth Defects Res A Clin Mol Teratol.; 70:572579 .

Reller, M. D.; Strickland, M. J.; Riehle-Colarusso, T.; Mahle, W. T. \& Correa, A. (2008): Prevalence of congenital heart defects in metropolitan Atlanta 1998-2005: J Pediatr.; 153:807-13.

Rogers, I.; Emmett, P.; Baker, D. \& Golding, J. (1998): Financial difficulties, smoking habits, composition of the diet and birthweight in a population of pregnant women in the south west of England: ALSPAC study team: Avon longitudinal study of pregnancy and childhood: Eur. J. Clin. Nutr; 52 (4), 251-260.

Sharpe, P. B.; Chan, A.; Haan, E. A. \& Hiller, J. E. (2005): Maternal diabetes and congenital anomalies in South Australia 1986-2000: a population-based cohort study: Birth Defects Res A Clin Mol Teratol.; 73:605-611.

Sheffield, J. S.; Butler-Koster, E. L.; Casey, B. M.; McIntire, D. D. \& Leveno, K. J. (2002): Maternal diabetes mellitus and infant malformations: Obstet Gynecol.; 100 (1):925-930.

Shi, H.; Yang, S.; Liu, Y.; Huang, P.; Lin, N.; Sun, X.; Yu, R.; Zhang, Y.; Qin, Y. \& Wang, L. (2015): Study on environmental causes and SNPs of MTHFR, MS and CBS genes related to congenital heart disease: PLoSONE; 10 (6): 1-10.

Simonneau, G.; Gatzoulis, M. A.; Adatia, I.; Celermajer, D.; Denton, C.; Ghofrani, A.; Gomez Sanchez, M. A.; Krishna, K. R.; Landzberg, M.; Machado, R. F.; Olschewski, H.; Robbins, I. M.; \& Souza, R. (2013): Updated clinical classification of pulmonary hypertension: J Am Coll Cardiol.; 62(D), 34-41.

Smeets, D. F. (2004): Historical prospective of human cytogenetics: from microscope to microarray: Clin Biochem.; 37(6), 439-46. 
Trevisan, P.; Diehl, Zen, T.; Machado, Rosa, R. F.; da Silva, J. N.; Koshiyama, D. B.; Paskulin, G. A. \& Gazzola, Zen, P. R. (2013): Chromosomal abnormalities in patients with congenital heart disease: Arq Bras Cardiol.; 101(6):495-501.

Verma, R. S. \& Babu, A. (1995): Banding techniques in: Verma RS, Babu A editors. Human chromosomes: Principles and techniques, $2^{\text {nd }}$ edition McGraw-Hill Inc, 72-133.

Werler, M. M.; Hayes, C.; Louik, C.; Shapiro, S. \& Mitchell, A. A. (1999): Multivitamin supplementation and risk of birth defects. Am J Epidemiol.; 150: 675-682.

Yang, J.; Carmichael, S. L.; Canfield, M.; Song, J. \& Shaw, G. M. (2008): Socioeconomic status in relation to selected birth defects in a large multicentered US casecontrol study: Am. J. Epidemiol; 167 (2), 145-154.

Zhang, Y.; Riehle-Colarusso, T.; Correa, A.; Li, S.; Feng, X.; Gindler, J.; Lin, H.; Webb, C.; Li, W.; Trines, J.; Berry, R. J.; Yeung, L.; Luo, Y.; Jiang, M.; Chen, H.; Sun, X.; \& Li, Z. (2011): Observed prevalence of congenital heart defects from a surveillance study in China: J Ultrasound Med.; 30:989-95.

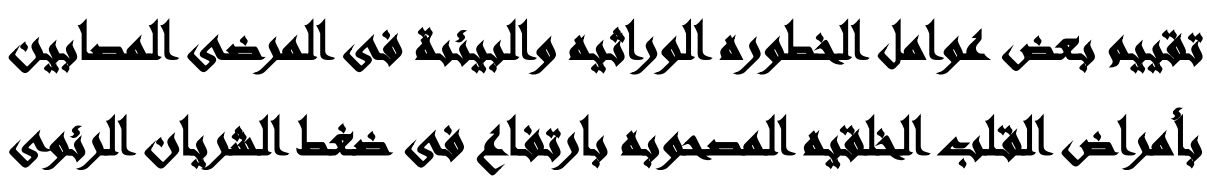

[؛]

$$
\begin{aligned}
& \text { مصطفى رجب(') - منى الروبى(Y) - امال محمد(Y) - سالى غريب عبد الله }
\end{aligned}
$$

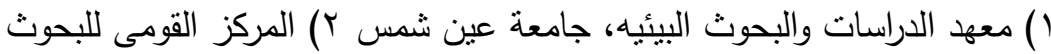

$$
\begin{aligned}
& \text { المستطلي }
\end{aligned}
$$

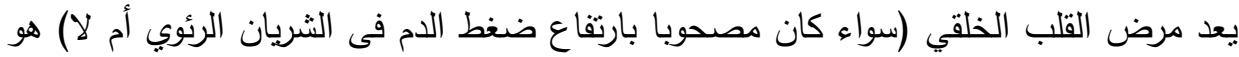

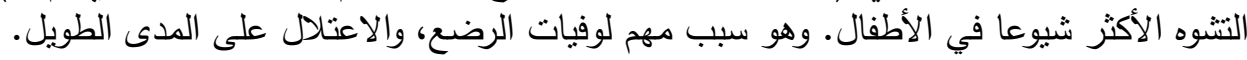

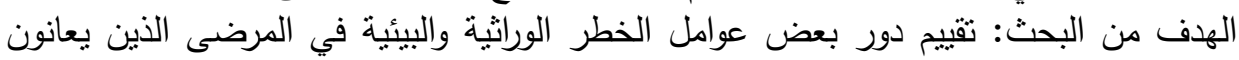

$$
\begin{aligned}
& \text { من أمراض القلب الخلقيه المصحوبه بارتفاع ضغط الثريان الرئوي. }
\end{aligned}
$$




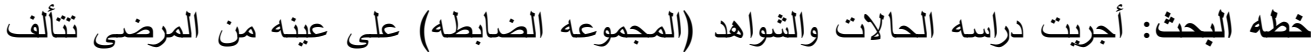

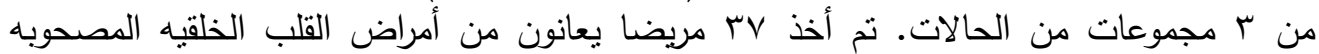

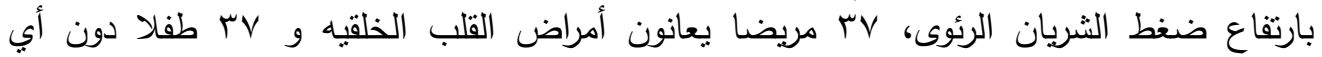

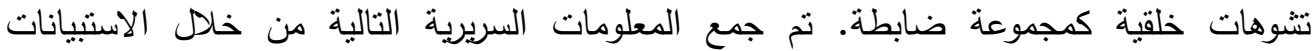

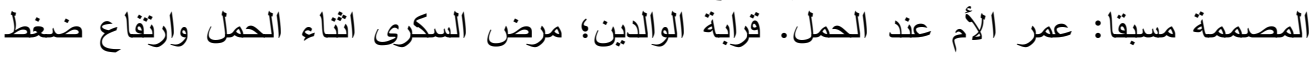

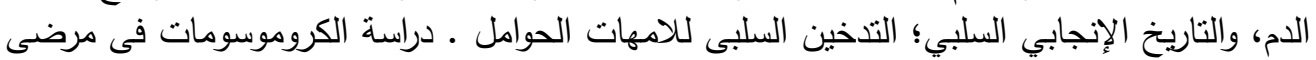

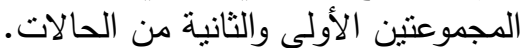

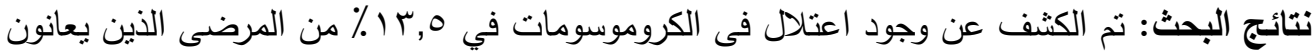

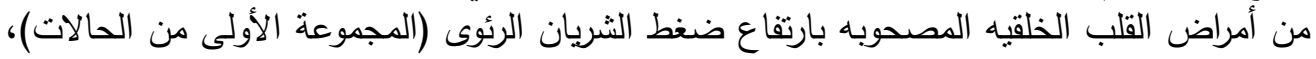

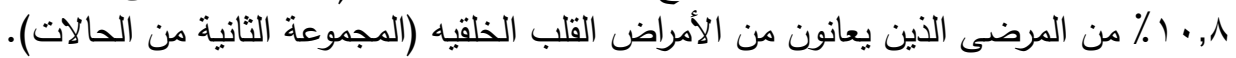

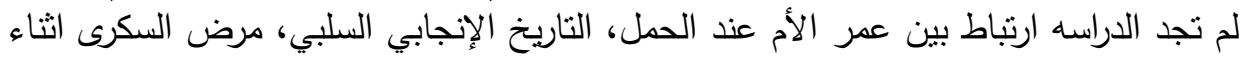

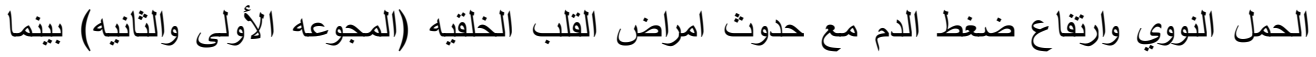

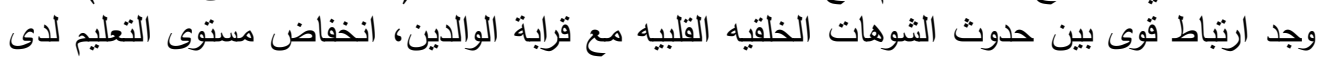

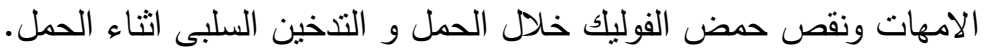
الاستتتاج والتوصيات: نجد أنه من الأهميه بمكان اتخاذ القرارات المناسبة وتتفيذ السياسات الرامية الراية الراتية

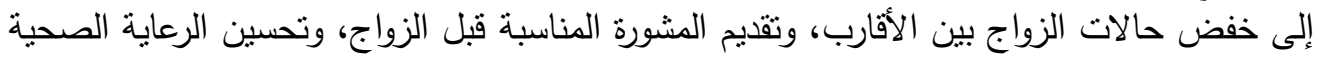

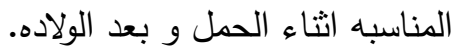

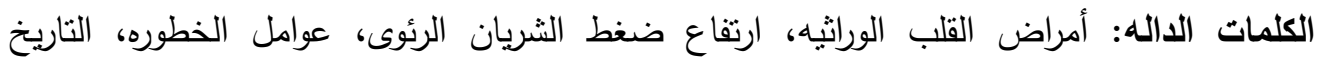

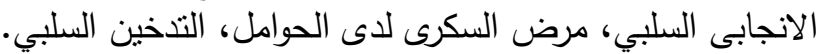

